\title{
Bolting, Yield, and Bulb Decay of Sweet Onion as Affected by Nitrogen Fertilization
}

\author{
Juan C. Díaz-Pérez, ${ }^{1}$ Albert C. Purvis, ${ }^{2}$ and J. Thad Paulk ${ }^{3}$ \\ Department of Horticulture, Coastal Plain Experiment Station, Tifton, GA 31793-0748
}

\begin{abstract}
AdDitional Index words. Allium cepa, seed-stem, flowering, vernalization, bulb quality
AbSTRaCt. Bolting causes significant economic losses in sweet onion (Allium cepa L.) production. Although temperature and photoperiod are considered to be the main factors that initiate bolting in onions, preliminary results suggested that low $\mathbf{N}$ fertilization rates increased bolting. The objective of our study was to determine the relationships of bolting, yield and bulb decay with $\mathrm{N}$ fertilization rates. The $\mathrm{N}$ fertilization rates applied ranged from the infraoptimal to the supraoptimal (from 102 to $302 \mathrm{~kg} \cdot \mathrm{ha}^{-1} \mathrm{~N}$ ). Shoot and bulb $\mathrm{N}$ content increased with increasing $\mathrm{N}$ rates, but there were no differences in the respective shoot and bulb $N$ contents among cultivars. Bolting incidence declined steadily with increasing $N$ fertilization rates up to 197 $\mathrm{kg} \cdot \mathrm{ha}^{-1} \mathrm{~N}$. Bolting incidence was among the highest in the cultivar Pegasus. The percent of decayed bulbs also increased at a steady rate with the rate of $\mathrm{N}$ applied. Total $\left(14.7 \mathrm{t} \cdot \mathrm{ha}^{-1}\right)$ and marketable $\left(0.8 \mathrm{t} \cdot \mathrm{ha}^{-1}\right)$ yields at the lowest $\mathrm{N}$ rate $(102$ $\left.\mathbf{k g} \cdot h^{-1} \mathrm{~N}\right)$ were lower $(P \leq \mathbf{0 . 0 1})$ than those at higher $\mathrm{N}$ rates. Rates of $\mathrm{N} \geq 145 \mathrm{~kg}^{-h^{-1}}$ had no significant effect on either total $\left(\right.$ mean $\left.=33.6 \mathrm{t} \cdot \mathrm{ha}^{-1}\right)$ or marketable $\left(\right.$ mean $\left.=21.6 \mathrm{t}^{\prime} \mathrm{ha}^{-1}\right)$ yields. Losses in marketable yield were primarily a combination of bolting and bulb decay and were minimized at $162 \mathrm{~kg}^{-h^{-1}} \mathrm{~N}$. Yield losses at low $\mathrm{N}$ rates were mostly due to bolting while yield losses at high $\mathbf{N}$ rates were mostly due to decay. Thus, excess applications of $\mathbf{N}$ fertilizer should be avoided since they have little effect on yields or bolting but they increase bulb decay.
\end{abstract}

Seed-stem formation (bolting) in onion (Allium cepa L.) produces poor quality bulbs with a hard center making them unmarketable (Rabinowitch, 1990). In Georgia, the production of 'Vidalia' type sweet onions may be severely limited by bolting, depending on the cultivar and the environmental conditions during the growing season (R.L. Torrance, personal comm.).

Plant age and several environmental factors influence the flowering process in onion plants (Brewster, 1997; Rabinowitch, 1990; Roberts et al., 1997; Scully et al., 1945). Although temperature and photoperiod both are important environmental factors affecting onion bolting (Brewster, 1997; Roberts et al., 1997), temperature has the greatest influence on inflorescence initiation and development (Rabinowitch, 1990). Flower initiation, however, occurs only after the emergence of a certain number of leaves, depending on the cultivar, followed by exposure of the plant to low, vernalizing temperatures (Brewster, 1985). Other factors affecting bolting include nitrogen and phosphorus fertilization (Brewster, 1983; Paterson et al., 1960; Stuart and Griffin, 1946). Bolting is usually variable from year to year and among cultivars (Rabinowitch, 1990).

Onions have been described as nitroneutral plants whose flowering dates are unaffected by N (Rabinowitch, 1990). A few studies, however, indicate that $\mathrm{N}$ nutrition influences the flowering process in onion (Brewster, 1983; Paterson, 1984; Paterson et al., 1960). Brewster (1983) reported that low $\mathrm{N}$ in the nutrient solution accelerated inflorescence initiation. The effects of $\mathrm{N}$ nutrition on onion bolting are still not fully understood.

Fertilization is an important variable in the production of mild, sweet onions. Although sulfur is the most important element in onion pungency, high $\mathrm{N}$ fertilization has been found to increase

Received for publication 13 May 2002. Accepted for publication 25 Oct. 2002. The editorial advice of K. Shackel is greatly appreciated. We are grateful to G. Mullinix for statistical assistance. We also thank G. Boyhan and D. Granberry for kindly reviewing the manuscript and E. Folds for secretarial support. Mention of trade names in this publication does not imply endorsement by the University of Georgia of products named, nor criticism of similar ones not mentioned.

${ }^{1}$ Assistant professor and corresponding author; e-mail jcdiaz@ tifton.uga.edu.

${ }^{2}$ Professor.

${ }^{3}$ Research technician. pungency (W.O. Chance and D.A. Smittle, personal communication). Low pungency and high sugar content are both important flavor attributes of Vidalia type onions.

This study was originally intended to evaluate the effects of $\mathrm{N}$ fertilization on yield and quality of three cultivars of sweet onion. However, serendipitously, results indicated a strong effect of $\mathrm{N}$ fertilization on bolting. Thus, in addition to the effects of $\mathrm{N}$ fertilization on yield and quality, this report also focuses on the effects of $\mathrm{N}$ fertilization on onion bolting.

\section{Materials and Methods}

The study was conducted at the Horticulture Farm, University of Georgia, Coastal Plain Experiment Station, Tifton, Ga. on a Tifton Sandy Loam soil (a fine loamy, silicious thermic Plinthic Paledults) with a pH of 6.5 to 6.8. Rye cover crop was used to minimize fertility differences among the plots prior to onion sowing. Onion was direct-seeded on 10 Oct. 1997 and 9 Oct. 1998 on 17-m-long, 0.9-m-wide beds formed on 1.8-m centers. Plants were spaced $0.15 \mathrm{~m}$ apart within rows on beds having four rows, with a $0.23 \mathrm{~m}$ separation between rows, and a final plant density of 144,000 plants/ha. Irrigation was applied as a complement to rainfall. From the sowing date to the period of rapid bulb enlargement plants were irrigated with an average of $25 \mathrm{~mm} \cdot \mathrm{week}^{-1}$ in one or two applications. From the period of bulb rapid enlargement to plant maturity, plants were irrigated with an average of 25 $\mathrm{mm} \cdot \mathrm{week}^{-1}$ in two or three applications.

The design was a split plot, with $\mathrm{N}$ fertility rate as the main plot and cultivar as the subplot. In the 1997-98 season, N fertilization rates were low $\left(146 \mathrm{~kg} \cdot \mathrm{ha}^{-1}\right)$, medium $\left(224 \mathrm{~kg} \cdot \mathrm{ha}^{-1}\right)$ and high $\left(302 \mathrm{~kg} \cdot \mathrm{ha}^{-1}\right)$. In the $1998-99$ season, $\mathrm{N}$ rates were very low $\left(102 \mathrm{~kg} \cdot \mathrm{ha}^{-1}\right)$, low $\left(147 \mathrm{~kg} \cdot \mathrm{ha}^{-1}\right)$, medium $\left(189 \mathrm{~kg} \cdot \mathrm{ha}^{-1}\right)$, and high $\left(234 \mathrm{~kg} \cdot \mathrm{ha}^{-1}\right)$. The cultivars used were 'Granex-33', 'Pegasus' and 'Cyclops' (all from Seminis Vegetable Seeds, Staticoy, Calif.). The $\mathrm{N}$ rates recommended in the Vidalia onion production area are 155 to $180 \mathrm{~kg} \cdot \mathrm{ha}^{-1}$ (Boyhan et al., 2001; Boyhan and Torrance, 2002). The dates of application and amounts and fertilizers used for 1997-98 and 1998-99 are shown in Table 1 and Table 2, respectively. The fertilization protocols were similar 
Table 1. Fertilization protocol of direct-seeded onion plants during the 1997-98 season.

\begin{tabular}{|c|c|c|c|c|c|c|c|c|c|c|}
\hline \multirow[b]{2}{*}{ Date } & \multirow{2}{*}{$\begin{array}{c}\text { Fertilizer } \\
\text { source }\end{array}$} & \multicolumn{3}{|c|}{ Low } & \multicolumn{3}{|c|}{ Medium } & \multicolumn{3}{|c|}{ High } \\
\hline & & $\mathrm{N}^{\mathrm{z}}$ & $\mathrm{P}^{\mathrm{z}}$ & $\mathrm{K}^{\mathrm{z}}$ & $\mathrm{N}$ & $\mathrm{P}$ & $\mathrm{K}$ & $\mathrm{N}$ & $\mathrm{P}$ & $\mathrm{K}$ \\
\hline 7 Oct & $5-10-15^{y}$ & 34 & 67 & 101 & 34 & 67 & 101 & 34 & 67 & 101 \\
\hline 7 Oct & $18-46-0^{x}$ & 26 & 67 & 0 & 26 & 67 & 0 & 26 & 67 & 0 \\
\hline $3 \mathrm{Nov}$ & $5-10-15$ & 17 & 34 & 50 & 17 & 34 & 50 & 17 & 34 & 50 \\
\hline $24 \mathrm{Nov}$ & $5-10-15$ & 17 & 34 & 50 & 17 & 34 & 50 & 17 & 34 & 50 \\
\hline 9 Jan & $15.5-0-0$ & 26 & 0 & 0 & 26 & 0 & 0 & 26 & 0 & 0 \\
\hline 21 Jan & $15.5-0-0$ & 0 & 0 & 0 & 0 & 0 & 0 & 26 & 0 & 0 \\
\hline 30 Jan & $15.5-0-0$ & 0 & 0 & 0 & 26 & 0 & 0 & 26 & 0 & 0 \\
\hline $10 \mathrm{Feb}$ & $15.5-0-0$ & 26 & 0 & 0 & 0 & 0 & 0 & 26 & 0 & 0 \\
\hline $20 \mathrm{Feb}$ & $15.5-0-0$ & 0 & 0 & 0 & 26 & 0 & 0 & 0 & 0 & 0 \\
\hline $24 \mathrm{Feb}$ & $15.5-0-0$ & 0 & 0 & 0 & 0 & 0 & 0 & 26 & 0 & 0 \\
\hline 9 Mar & $15.5-0-0$ & 0 & 0 & 0 & 0 & 0 & 0 & 26 & 0 & 0 \\
\hline 13 Mar & $15.5-0-0$ & 0 & 0 & 0 & 26 & 0 & 0 & 0 & 0 & 0 \\
\hline 27 Mar & $15.5-0-0$ & 0 & 0 & 0 & 0 & 0 & 0 & 26 & 0 & 0 \\
\hline 31 Mar & $15.5-0-0$ & 0 & 0 & 0 & 26 & 0 & 0 & 0 & 0 & 0 \\
\hline $10 \mathrm{Apr}$ & $15.5-0-0$ & 0 & 0 & 0 & 0 & 0 & 0 & 26 & 0 & 0 \\
\hline Total & & 146 & 202 & 201 & 224 & 202 & 201 & 302 & 202 & 201 \\
\hline
\end{tabular}

${ }_{\mathrm{z}} \mathrm{N}, \mathrm{P}$, and $\mathrm{K}$ in $\mathrm{kg} \cdot \mathrm{ha}^{-1}$.

${ }^{\mathrm{y}}$ Applied as calcium nitrate.

${ }^{\mathrm{x}}$ Applied as diamonium phosphate.

to those used by commercial growers in Georgia. Bolting incidence was determined on 4 May 1998 and 12 May 1999 as the percent of plants with seed stems.

Plants were harvested when $20 \%$ of the necks of each cultivar had collapsed (tops down). Whole plants (bulb + top) and bulbs were weighed immediately after the plants were removed from the soil and submitted to curing. Bulbs were cured for $2 \mathrm{~d}$ in a greenhouse and $5 \mathrm{~d}$ in a dryer at $37^{\circ} \mathrm{C}$ air temperature $(50 \%$ to $65 \% \mathrm{RH}$ ) and a linear air velocity of $5 \mathrm{~m} \cdot \mathrm{min}^{-1}$ through the stack of onions (Boyhan et al., 2001). After curing, bulbs were graded by size and appearance, counted and weighed. Bulbs were graded into grades as marketable (U.S. No. 1, U.S. No. 2) and culls (USDA, 1995). The number and weight of marketable 'Jumbo' bulbs (diameter $>76 \mathrm{~mm}$ ) were also determined. Bulb decay incidence was determined as the percent bulbs with any visible decay relative to the total number of bulbs. Prior to storage, bulbs and shoots were sampled for tissue $\mathrm{N}$ analysis. Tissue $\mathrm{N}$ content was determined by the copper catalyst (AOAC, 1990).

In 1997-98, a group of 50 marketable bulbs for each cultivar (except 'Cyclops') $\times \mathrm{N}$ rate combination for each of the medium, large and jumbo bulbs was stored in either air or controlledatmosphere at $3 \% \mathrm{O}_{2}+5 \% \mathrm{CO}_{2}+92 \% \mathrm{~N}_{2}\left(\mathrm{CA}_{1}\right)$ or $2 \% \mathrm{O}_{2}+5 \%$
$\mathrm{CO}_{2}+93 \% \mathrm{~N}_{2}\left(\mathrm{CA}_{2}\right)$ for 4 or 8 months at $1{ }^{\circ} \mathrm{C}$. After each storage period, the number and weight of the marketable and cull (decayed) bulbs were determined.

Data were analyzed using the Mixed Procedure of SAS (SAS Institute Inc., 2000). The relationships for shoot and bulb $\mathrm{N}$ content vs. applied $\mathrm{N}$, and percent decayed bulbs vs. applied $\mathrm{N}$ and bulb $\mathrm{N}$ content were determined by linear regression analysis. The relationships of bolting vs. applied $\mathrm{N}$ and bulb $\mathrm{N}$ content, and total and marketable yield vs. applied $\mathrm{N}$ were determined by segmented-linear regression analysis (Anderson and Nelson, 1975; Argo and Bierbaum, 1996), using SAS's nonlinear regression procedure (NLIN).

\section{Results}

Bolting. In both seasons, 'Pegasus' had among the highest bolting incidences (Table 3 and 4), and bolting was highest at the lowest $\mathrm{N}$ rate. Data, pooled for season and cultivar, indicated that bolting incidence declined steadily with increasing $\mathrm{N}$ rates up to 197 $\mathrm{kg} \cdot \mathrm{ha}^{-1} \mathrm{~N}$ (Fig. 1). This value was calculated as the intersection point of the two lines in Fig. 1. Average bolting incidence was $7.2 \%$ at $\geq 197 \mathrm{~kg} \cdot \mathrm{ha}^{-1} \mathrm{~N}$. The average bolting incidence for the season was

Table 2. Fertilization protocol of direct-seeded onion plants during the 1998-99 season.

\begin{tabular}{|c|c|c|c|c|c|c|c|c|c|c|c|c|c|}
\hline \multirow[b]{2}{*}{ Date } & \multirow[b]{2}{*}{ Fertilizer } & \multicolumn{3}{|c|}{ Very low } & \multicolumn{3}{|c|}{ Low } & \multicolumn{3}{|c|}{ Medium } & \multicolumn{3}{|c|}{ High } \\
\hline & & $\mathrm{N}^{\mathrm{z}}$ & $\mathrm{P}^{\mathrm{z}}$ & $\mathrm{K}^{\mathrm{z}}$ & $\mathrm{N}$ & $\mathrm{P}$ & K & $\mathrm{N}$ & $\mathrm{P}$ & $\mathrm{K}$ & $\mathrm{N}$ & $\mathrm{P}$ & K \\
\hline$\overline{6 \text { Oct }^{y}}$ & $5-10-15$ & 58 & 115 & 174 & 58 & 115 & 174 & 58 & 115 & 174 & 58 & 115 & 174 \\
\hline 7 Oct & $18-46-0$ & 26 & 67 & 0 & 26 & 67 & 0 & 26 & 67 & 0 & 26 & 67 & 0 \\
\hline $1 \mathrm{Dec}$ & $5-10-15$ & 18 & 37 & 55 & 18 & 37 & 55 & 18 & 37 & 55 & 18 & 37 & 55 \\
\hline 11 Jan & $15-0-14$ & 0 & 0 & 0 & 9 & 0 & 8 & 17 & 0 & 16 & 26 & 0 & 24 \\
\hline $8 \mathrm{Feb}$ & $15-0-14$ & 0 & 0 & 0 & 9 & 0 & 8 & 17 & 0 & 16 & 26 & 0 & 24 \\
\hline $23 \mathrm{Feb}$ & $15-0-14$ & 0 & 0 & 0 & 9 & 0 & 8 & 17 & 0 & 16 & 26 & 0 & 24 \\
\hline $10 \mathrm{Mar}$ & $15.5-0-0$ & 0 & 0 & 0 & 9 & 0 & 0 & 18 & 0 & 0 & 27 & 0 & 0 \\
\hline 22 Mar & $15.5-0-0$ & 0 & 0 & 0 & 9 & 0 & 0 & 18 & 0 & 0 & 27 & 0 & 0 \\
\hline Total & & 102 & 219 & 229 & 147 & 219 & 253 & 189 & 220 & 277 & 234 & 219 & 301 \\
\hline
\end{tabular}

${ }^{\mathrm{z}} \mathrm{N}, \mathrm{P}$, and $\mathrm{K}$ in $\mathrm{kg} \cdot \mathrm{ha}^{-1}$.

${ }^{\mathrm{y}}$ Seeding date. 
Table 3. Effect of cultivar and rate of nitrogen fertilization on bolting incidence and bulb and shoot nitrogen content of sweet onion grown in Tifton, Ga. during the1997-98 season.

\begin{tabular}{lccc}
\hline \hline Treatment & Bolting (\%) & Bulb N (\%) & Shoot N (\%) \\
\hline Cultivar & & & \\
Cyclops & $8 \mathrm{~b}^{\mathrm{z}}$ & $1.7 \mathrm{a}$ & $2.7 \mathrm{a}$ \\
Granex & $16 \mathrm{ab}$ & $1.8 \mathrm{a}$ & $2.5 \mathrm{a}$ \\
Pegasus & $23 \mathrm{a}$ & $1.6 \mathrm{a}$ & $2.6 \mathrm{a}$ \\
Nitrogen rate & & & \\
Low & $38 \mathrm{a}$ & $1.0 \mathrm{~b}$ & $1.9 \mathrm{~b}$ \\
Medium & $6 \mathrm{~b}$ & $2.0 \mathrm{a}$ & $3.0 \mathrm{a}$ \\
High & $5 \mathrm{~b}$ & $2.1 \mathrm{a}$ & $3.0 \mathrm{a}$ \\
Significance & & & \\
Cultivar (C) & 0.03 & 0.02 & 0.84 \\
Nitrogen $(\mathrm{N})$ & $<0.01$ & $<0.01$ & $<0.01$ \\
C $\times$ N & 0.72 & 0.81 & 0.80
\end{tabular}

${ }^{\mathrm{z}}$ Mean separation within columns for cultivar or $\mathrm{N}$ rate by duncan's multiple range test $(P<0.05)$.

lower in 1997-98 (16\%) than in 1998-99 (38\%) (Tables 3 and 4).

SHOOT AND BULb N CONTENT. There were no differences in bulb and shoot $\mathrm{N}$ content among cultivars during the two seasons (Tables 3 and 4). As expected, bulb and shoot $\mathrm{N}$ contents increased with increasing $\mathrm{N}$ rates, and did not differ between seasons. No cultivar $\times \mathrm{N}$ rate interaction was found on bulb and shoot $\mathrm{N}$ contents. When season and cultivar data were pooled, bulb and shoot $\mathrm{N}$ content increased at a steady rate with increasing rates of $\mathrm{N}$ fertilization (Fig. 2). Bolting decreased steadily with increasing bulb $\mathrm{N}$ content until bulb $\mathrm{N}$ content was $1.7 \%$ (intersection point of the lines in Fig. 3) and then leveled off at higher bulb $\mathrm{N}$ contents. Average bolting incidence was $6.3 \%$ at bulb N $\geq 1.7 \%$. Similarly, bolting decreased at a steady rate with increasing shoot $\mathrm{N}$ content, with no effects on bolting at shoot $\mathrm{N}$ content $>2 \%$ (data not shown).

INCIDENCE OF BULB DECAY. High $\mathrm{N}$ fertilization rates were detrimental to bulb quality. The percent of decayed bulbs increased linearly with both $\mathrm{N}$ applied and bulb $\mathrm{N}$ content (Fig. 4). After a 4-month storage, the percent of decayed bulbs was unaffected by cultivar (mean $=25 \%$ ), CA storage, bulb size, or $\mathrm{N}$

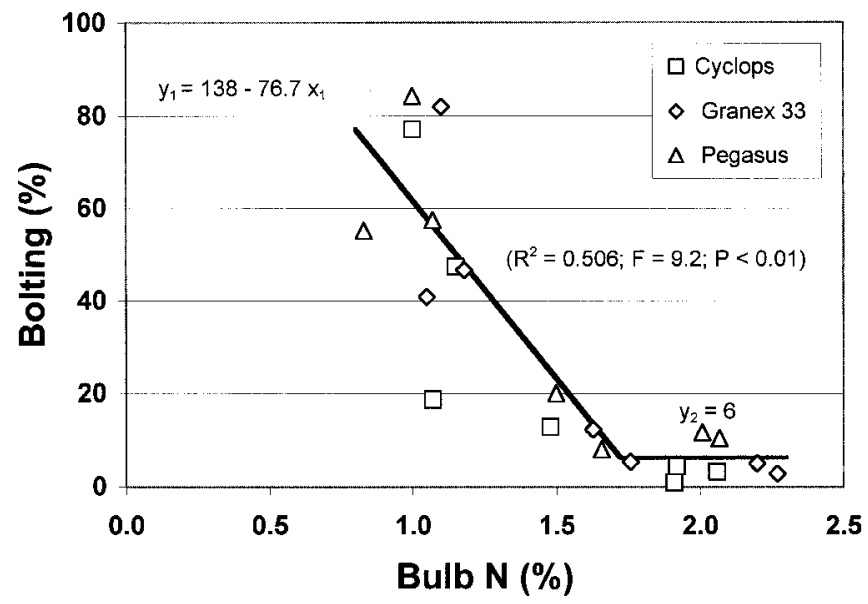

Fig. 1. Onion bolting (seed-stem formation) incidence as affected by the amount of nitrogen applied. Data were pooled over seasons (1997-98 and 1998-99). Each symbol represents the mean for the cultivar at each $\mathrm{N}$ rate. The two solids lines were fitted by nonlinear regression. The point of intersection of the two lines was at $\mathrm{x}=197$ and $\mathrm{y}=7.2$. The $r^{2}$ values were calculated as: $1-\left[\sum\left(\mathrm{SS}_{\text {errors }}\right) /\right.$ $\mathrm{SS}_{\text {corrected total }}$.
Table 4. Effect of cultivar and rate of nitrogen fertilization on bolting incidence and bulb and shoot nitrogen content of sweet onion grown in Tifton, Ga. during the 1998-99 season.

\begin{tabular}{lccc}
\hline \hline Treatment & Bolting (\%) & Bulb N (\%) & Shoot N (\%) \\
\hline Cultivar & & & \\
Cyclops & $35 \mathrm{~b}^{\mathrm{z}}$ & $1.4 \mathrm{a}$ & $1.7 \mathrm{a}$ \\
Granex & $36 \mathrm{~b}$ & $1.4 \mathrm{a}$ & $1.7 \mathrm{a}$ \\
$\quad$ Pegasus & $42 \mathrm{a}$ & $1.3 \mathrm{a}$ & $1.7 \mathrm{a}$ \\
Nitrogen rate & & & \\
$\quad$ Very low & $81 \mathrm{a}$ & $1.0 \mathrm{c}$ & $1.5 \mathrm{c}$ \\
Low & $50 \mathrm{~b}$ & $1.1 \mathrm{c}$ & $1.5 \mathrm{c}$ \\
Medium & $15 \mathrm{c}$ & $1.5 \mathrm{~b}$ & $1.8 \mathrm{~b}$ \\
High & $6 \mathrm{~d}$ & $1.8 \mathrm{a}$ & $1.9 \mathrm{a}$ \\
Significance & & & \\
Cultivar $(\mathrm{C})$ & $<0.01$ & 0.34 & 0.63 \\
Nitrogen $(\mathrm{N})$ & $<0.01$ & $<0.01$ & $<0.01$ \\
C $\times$ N & 0.76 & 0.84 & 0.44
\end{tabular}

${ }^{2}$ Mean separation within columns for cultivar or $\mathrm{N}$ rate by duncan multiple range test $(P<0.05)$.

rate (data not shown). After an 8-month storage, the percent of decayed bulbs was higher $(P \leq 0.05)$ in 'Pegasus' $(63 \%)$ than in 'Granex 33' (52\%) and it was higher $(P \leq 0.01)$ in air $(70 \%)$ than under $\mathrm{CA}_{1}(56 \%)$ or $\mathrm{CA}_{2}(43 \%)$ storage, but it was not affected by bulb size or $\mathrm{N}$ fertilization.

YIELDS. In 1997-98, number and weight of jumbo bulbs were lowest in 'Pegasus' (Table 5). The number of marketable bulbs was similar among cultivars, while the weight of marketable bulbs in 'Cyclops' was among the highest and in 'Pegasus' among the lowest. The highest number and weight of cull bulbs and the total number of bulbs was highest in 'Pegasus', while the total weight of bulbs was highest in 'Cyclops'. Individual bulb weight was highest in 'Cyclops' and lowest in 'Pegasus', while top weight was highest in 'Granex 33'. In 1998-99, the number of jumbo and marketable bulbs and bulb weights in all grade categories were similaramong cultivars (Table6). Numbers of cull bulbs and total bulb number were highest in 'Granex 33'. As in the previous

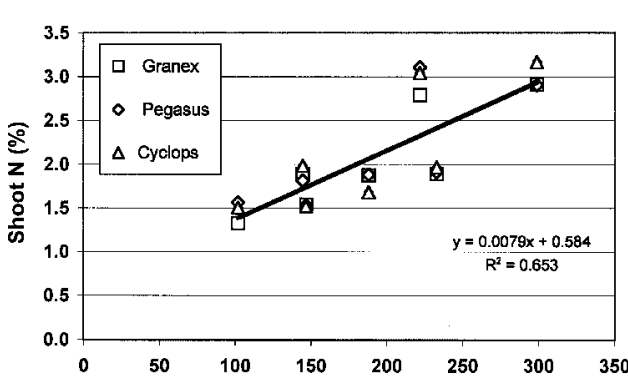
year,individualbulb weight was highest in 'Cyclops'.

In 1997-98, number of jumbo bulbs was similar among $\mathrm{N}$ fertilization rates, while weight of jumbo bulbs at low $\mathrm{N}$ was

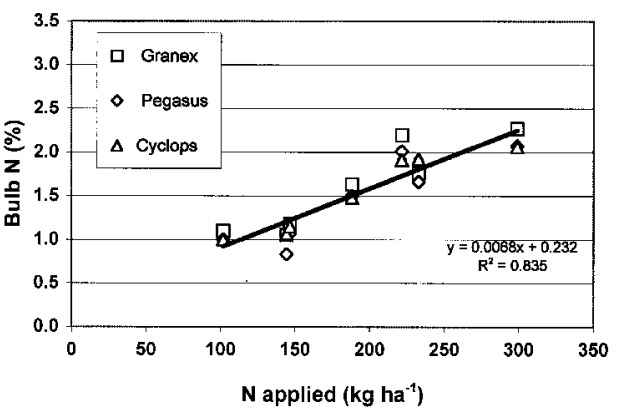
among the highest (Table 5). Number of marketable bulbs athighNwasamong the highest, while weight of marketablebulbs wassimilar among $\mathrm{N}$ rates. Numberandweight of cull bulbs were highest at low $\mathrm{N}$. Total bulb number

Fig. 2. Bulb and shoot nitrogen content as affected by the amount of nitrogen applied. Data were pooled over seasons (1997-98 and 1998-99). Each symbol represents the mean for the cultivar at each $\mathrm{N}$ rate. Solids lines were fitted by linear regression. 


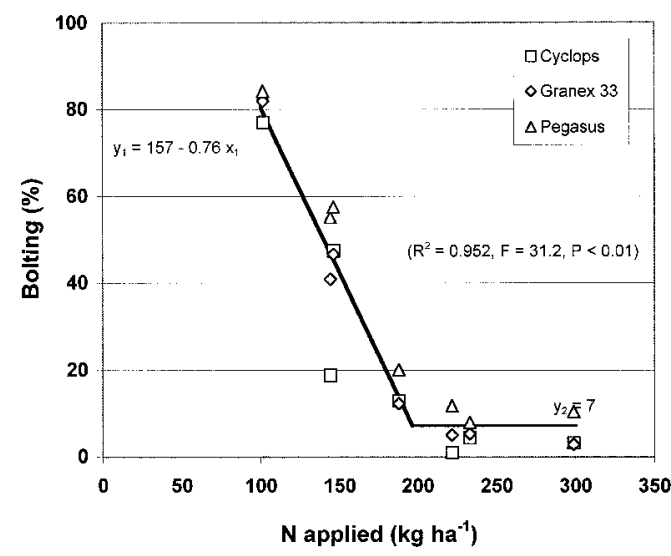

Fig. 3. Incidence of onion bolting as affected by bulb nitrogen content. Data were pooled over seasons(1997-98and 1998-99). Each symbol represents the mean for the cultivar at each $\mathrm{N}$ rate. The two solids lines were fitted by nonlinear regression. The point of intersection of the two lines was at $\mathrm{x}=$ 1.7 and $\mathrm{y}=6$. The $r^{2}$ values were calculatedas $1-\left[\sum\left(\mathrm{SS}_{\text {errors }}\right)\right]$ $\left.\mathrm{SS}_{\text {corrected total }}\right]$ nonlinear regression, resulted in a nonsignificant $F$ value. Slopes near zero were obtained when both total and marketable yields at the lowest $\mathrm{N}$ rate $\left(102 \mathrm{~kg} \cdot \mathrm{ha}^{-1} \mathrm{~N}\right)$ were not considered in the regression analysis. Yield data were then analyzed considering two groups: Group 1 included the yields at the lowest $\mathrm{N}$ rate, while Group 2 was comprised of the remaining yield data. A $t$ test was use to determine whether the respective yield means of Groups 1 and 2 were significantly different from each other (Steel and Torrie, 1980). Total (33.6 th.ha $\left.{ }^{-1}\right)$ and marketable $\left(14.7 \mathrm{t} \cdot \mathrm{ha}^{-1}\right)$ yields at the lowest $\mathrm{N}$ rate were lower $(P \leq 0.01)$ than those at higher $\mathrm{N}$ rates (Fig. 5). $\mathrm{N}$ fertilization rates $\geq 146 \mathrm{~kg} \cdot \mathrm{ha}^{-1}$ had no significant effect on either total $\left(\right.$ mean $\left.=33.6 \mathrm{t} \cdot \mathrm{ha}^{-1}\right)$ or marketable $\left(\right.$ mean $\left.=21.6 \mathrm{t} \cdot \mathrm{ha}^{-1}\right)$ yields .

Losses in marketable yield were primarily a combination of bolting and bulb decay. Percent yield loss (percent bolting + percent decay) decreased with increasing $\mathrm{N}$ rate up to a minimum yield loss at 162 $\mathrm{kg} \cdot \mathrm{ha}^{-1} \mathrm{~N}$, followed with increasing yield losses at $>162 \mathrm{~kg} \cdot \mathrm{ha}^{-1} \mathrm{~N}$ (Fig. 6).

\section{Discussion}

Bolting was associated with low $\mathrm{N}$ fertilization rates and low bulb $\mathrm{N}$ content (Fig. 1, Tables 3-4). Our results support other reports that $\mathrm{N}$ fertilization decreases onion bolting (Brewster, 1983; Paterson et al.,
Fig. 4. Bulb decay incidence as affected by the amount of nitrogen fertilizer applied and bulb nitrogen content. Data were pooled over seasons (1997-98 and 1998-99). Each symbol represents the mean for the cultivar at each $\mathrm{N}$ rate. Solids lines were fitted by linear regression.

and weight and individual bulb weight were similar among $\mathrm{N}$ rates. Top (shoot) weight was lowest at medium N. In 1998-99, number and weight of jumbo and marketable bulbs were lowest at very low $\mathrm{N}$ and highest at medium and high $\mathrm{N}$ (Table 6). The number of cull bulbs was highest at very low $\mathrm{N}$ and lowest at medium and high $\mathrm{N}$, while the weight of cull bulbs was highest at low $\mathrm{N}$. The total number of bulbs was among the lowest at high $\mathrm{N}$, while total bulb weight was lowest at very low N. Individual bulb weight was lowest at very low $\mathrm{N}$, while it was similar among the other $\mathrm{N}$ rates.

Total and marketable yield data, pooled for the two seasons and three cultivars and analyzed as a function of $\mathrm{N}$ applied by
1960), although temperature and photoperiod are usually considered the determinant factors in onion bolting (Roberts et al., 1997). It is possible that some of the bolting responses previously attributed primarily to low temperature might also involve nutritional effects since low temperature has been shown to reduce nutrient uptake, particularly N and P uptake (Marschner, 1995).

Bolting varied among cultivars, with 'Pegasus' having among the highest incidence regardless of the $\mathrm{N}$ fertilization rate. This result is consistent with previous reports indicating that genotype influences onion bolting (Rabinowitch, 1990). To our knowledge, there are no short-day cultivars of sweet onion that are resistant to bolting. Thus, cultural practices are one option growers have to reduce bolting in the crop.

Klebs reported that low carbon-to-nitrogen $(\mathrm{C} / \mathrm{N})$ ratio favors vegetative growth while high $\mathrm{C} / \mathrm{N}$ ratio favors reproductive growth of horticultural plants (Klebs, 1918 cited by Dennis,

Table 5. Effect of cultivar and rate of nitrogen fertilization on yield and top weight of sweet onion grown in 1997-98.

\begin{tabular}{|c|c|c|c|c|c|c|c|c|c|c|}
\hline \multirow[b]{2}{*}{ Effect } & \multicolumn{2}{|c|}{ Jumbo } & \multicolumn{2}{|c|}{ Marketable } & \multicolumn{2}{|c|}{ Cull } & \multicolumn{2}{|c|}{ Total yield } & \multirow{2}{*}{$\begin{array}{c}\text { Bulb } \\
\text { wt } \\
\text { (kg/bulb) }\end{array}$} & \multirow{2}{*}{$\begin{array}{c}\text { Top } \\
\text { wt } \\
\left(t \cdot h a^{-1}\right)\end{array}$} \\
\hline & $\begin{array}{c}\text { No. } \\
\left(10^{3} \cdot \mathrm{ha}^{-1}\right)\end{array}$ & $\begin{array}{c}\text { Yield } \\
\left(\mathrm{t} \cdot \mathrm{ha}^{-1}\right)\end{array}$ & $\begin{array}{c}\text { No. } \\
\left(10^{3} \cdot \mathrm{ha}^{-1}\right)\end{array}$ & $\begin{array}{l}\text { Yield } \\
\left(\mathrm{t} \cdot \mathrm{ha}^{-1}\right)\end{array}$ & $\begin{array}{c}\text { No. } \\
\left(10^{3} \cdot \mathrm{ha}^{-1}\right)\end{array}$ & $\begin{array}{l}\text { Yield } \\
\left(\mathrm{t} \cdot \mathrm{ha}^{-1}\right)\end{array}$ & $\begin{array}{c}\text { No. } \\
\left(10^{3} \cdot \mathrm{ha}^{-1}\right)\end{array}$ & $\begin{array}{l}\text { Yield } \\
\left(t \cdot h a^{-1}\right)\end{array}$ & & \\
\hline \multicolumn{11}{|l|}{$\overline{\text { Cultivar (C) }}$} \\
\hline Cyclops & $24.2 \mathrm{a}$ & $10.5 \mathrm{a}$ & $95.3 \mathrm{a}$ & $27.6 \mathrm{a}$ & $33.3 \mathrm{~b}$ & $8.3 \mathrm{a}$ & $128.7 \mathrm{~b}$ & $35.9 \mathrm{a}$ & $0.280 \mathrm{a}$ & $8.3 \mathrm{~b}$ \\
\hline Granex 33 & $25.0 \mathrm{a}$ & $9.7 \mathrm{a}$ & $98.2 \mathrm{a}$ & $26.1 \mathrm{ab}$ & $22.5 \mathrm{c}$ & $4.2 \mathrm{~b}$ & $120.9 \mathrm{~b}$ & $30.3 \mathrm{~b}$ & $0.251 \mathrm{~b}$ & $13.8 \mathrm{a}$ \\
\hline Pegasus & $10.1 \mathrm{~b}$ & $4.0 \mathrm{~b}$ & $98.1 \mathrm{a}$ & $22.2 \mathrm{~b}$ & $49.9 \mathrm{a}$ & $8.3 \mathrm{a}$ & $148.3 \mathrm{a}$ & $30.6 \mathrm{~b}$ & $0.207 \mathrm{c}$ & $10.0 \mathrm{~b}$ \\
\hline \multicolumn{11}{|l|}{$\mathrm{N}$ rate } \\
\hline Low & $19.8 \mathrm{a}$ & $8.2 \mathrm{a}$ & 89.1 b & $23.5 \mathrm{a}$ & $46.4 \mathrm{a}$ & $7.5 \mathrm{a}$ & $135.7 \mathrm{a}$ & $31.1 \mathrm{a}$ & $0.234 \mathrm{a}$ & $13.2 \mathrm{a}$ \\
\hline Medium & $19.0 \mathrm{a}$ & $7.4 \mathrm{ab}$ & $100.4 \mathrm{ab}$ & $25.5 \mathrm{a}$ & $27.2 \mathrm{~b}$ & $5.3 \mathrm{~b}$ & $127.8 \mathrm{a}$ & $30.1 \mathrm{a}$ & $0.244 \mathrm{a}$ & $10.0 \mathrm{~b}$ \\
\hline High & $16.2 \mathrm{a}$ & $6.0 \mathrm{~b}$ & $105.6 \mathrm{a}$ & $24.8 \mathrm{a}$ & $31.8 \mathrm{~b}$ & $6.5 \mathrm{ab}$ & $137.7 \mathrm{a}$ & $31.3 \mathrm{a}$ & $0.228 \mathrm{a}$ & $12.2 \mathrm{a}$ \\
\hline \multicolumn{11}{|l|}{ Significance } \\
\hline C & $<0.001$ & $<0.001$ & 0.877 & 0.028 & $<0.001$ & $<0.001$ & $<0.001$ & 0.009 & $<0.001$ & $<0.001$ \\
\hline $\mathrm{N}$ & 0.110 & 0.027 & 0.469 & 0.537 & 0.005 & 0.143 & 0.885 & 0.165 & 0.083 & 0.046 \\
\hline $\mathrm{C} \times \mathrm{N}$ & 0.176 & 0.045 & 0.141 & 0.286 & 0.010 & 0.002 & 0.299 & 0.067 & 0.004 & 0.559 \\
\hline
\end{tabular}

${ }^{\mathrm{z}}$ Mean separation within columns for cultivar or $\mathrm{N}$ rate by Duncan's multiple range test $(P<0.05)$. 
Table 6. Effect of cultivar and rate of nitrogen fertilization on yield and top weight of sweet onion grown during 1998-99.

\begin{tabular}{|c|c|c|c|c|c|c|c|c|c|}
\hline \multirow[b]{2}{*}{ Effect } & \multicolumn{2}{|c|}{ Jumbo } & \multicolumn{2}{|c|}{ Marketable } & \multicolumn{2}{|c|}{ Cull } & \multicolumn{2}{|c|}{ Total yield } & \multirow{2}{*}{$\begin{array}{c}\text { Bulb } \\
\text { wt } \\
\text { (kg/bulb) }\end{array}$} \\
\hline & $\begin{array}{c}\text { No. } \\
\left(10^{3} \cdot \mathrm{ha}^{-1}\right)\end{array}$ & $\begin{array}{c}\text { Yield } \\
\left(\mathrm{t} \cdot \mathrm{ha}^{-1}\right)\end{array}$ & $\begin{array}{c}\text { No. } \\
\left(10^{3} \cdot \mathrm{ha}^{-1}\right)\end{array}$ & $\begin{array}{l}\text { Yield } \\
\left(\mathrm{t} \cdot \mathrm{ha}^{-1}\right)\end{array}$ & $\begin{array}{c}\text { No. } \\
\left(10^{3} \cdot \mathrm{ha}^{-1}\right)\end{array}$ & $\begin{array}{c}\text { Yield } \\
\left(\mathrm{t} \cdot \mathrm{ha}^{-1}\right)\end{array}$ & $\begin{array}{c}\text { No. } \\
\left(10^{3} \cdot \mathrm{ha}^{-1}\right)\end{array}$ & $\begin{array}{l}\text { Yield } \\
\left(\mathrm{t} \cdot \mathrm{ha}^{-1}\right.\end{array}$ & \\
\hline \multicolumn{10}{|l|}{$\overline{\text { Cultivar (C) }}$} \\
\hline Cyclops & $24.9 \mathrm{a}$ & $13.5 \mathrm{a}$ & $28.7 \mathrm{a}$ & $14.5 \mathrm{a}$ & $50.1 \mathrm{~b}$ & $17.0 \mathrm{a}$ & $79.6 \mathrm{~b}$ & $31.5 \mathrm{a}$ & $0.41 \mathrm{a}$ \\
\hline Granex 33 & $25.6 \mathrm{a}$ & $12.3 \mathrm{a}$ & $31.8 \mathrm{a}$ & $14.0 \mathrm{a}$ & $71.8 \mathrm{a}$ & $17.1 \mathrm{a}$ & $103.5 \mathrm{a}$ & $31.9 \mathrm{a}$ & $0.30 \mathrm{~b}$ \\
\hline Pegasus & $23.1 \mathrm{a}$ & $11.9 \mathrm{a}$ & $28.3 \mathrm{a}$ & $13.0 \mathrm{a}$ & $57.4 \mathrm{ab}$ & $14.6 \mathrm{a}$ & $85.7 \mathrm{~b}$ & $27.6 \mathrm{a}$ & $0.34 \mathrm{~b}$ \\
\hline \multicolumn{10}{|l|}{$\mathrm{N}$ rate } \\
\hline Very low & $1.3 \mathrm{c}$ & $0.7 \mathrm{c}$ & $2.6 \mathrm{c}$ & $0.8 \mathrm{c}$ & $93.9 \mathrm{a}$ & $14.0 \mathrm{~b}$ & $96.6 \mathrm{a}$ & $14.8 \mathrm{c}$ & $0.15 \mathrm{~b}$ \\
\hline Low & $23.3 \mathrm{~b}$ & $13.1 \mathrm{~b}$ & $27.8 \mathrm{~b}$ & $10.4 \mathrm{~b}$ & $76.8 \mathrm{~b}$ & $25.6 \mathrm{a}$ & $104.7 \mathrm{a}$ & $39.6 \mathrm{a}$ & $0.39 \mathrm{a}$ \\
\hline Medium & $38.2 \mathrm{a}$ & $19.1 \mathrm{a}$ & $46.0 \mathrm{a}$ & $21.3 \mathrm{a}$ & $38.9 \mathrm{c}$ & $14.4 \mathrm{~b}$ & $84.9 \mathrm{ab}$ & $35.7 \mathrm{ab}$ & $0.43 \mathrm{a}$ \\
\hline High & $33.9 \mathrm{a}$ & $16.8 \mathrm{ab}$ & $40.1 \mathrm{ab}$ & $18.5 \mathrm{ab}$ & $28.7 \mathrm{c}$ & $10.1 \mathrm{~b}$ & $68.8 \mathrm{~b}$ & $28.6 \mathrm{~b}$ & $0.43 \mathrm{a}$ \\
\hline \multicolumn{10}{|l|}{ Significance } \\
\hline $\mathrm{C}$ & 0.872 & 0.742 & 0.741 & 0.835 & 0.023 & 0.494 & 0.031 & 0.430 & $<0.001$ \\
\hline $\mathrm{N}$ & $<0.001$ & $<0.001$ & $<0.001$ & $<0.001$ & $<0.001$ & $<0.001$ & 0.013 & $<0.001$ & $<0.001$ \\
\hline $\mathrm{C} \times \mathrm{N}$ & 0.751 & 0.736 & 0.823 & 0.923 & 0.152 & 0.049 & 0.223 & 0.248 & 0.184 \\
\hline
\end{tabular}

${ }^{\mathrm{z}}$ Mean separation within columns for cultivar or $\mathrm{N}$ rate by Duncan's multiple range test $(P<0.05)$.

1984). The plants' C/N ratio can be reduced by horticultural practices such as pruning, resulting in inhibition of flowering. The $\mathrm{C} / \mathrm{N}$ ratio determines whether the onion plant remains vegetative or produces a flower stalk (Rabinowitch, 1990). In onion, root pruning inhibits the flowering process by promoting root growth (Sanders and Cure, 1996). Nitrogen fertilization is another way to modify the plant's $\mathrm{C} / \mathrm{N}$ ratio. We found that bulb $\mathrm{N}$ content increased with $\mathrm{N}$ fertilization rate, and that bolting decreased steadily with increasing bulb and shoot $\mathrm{N}$ contents.
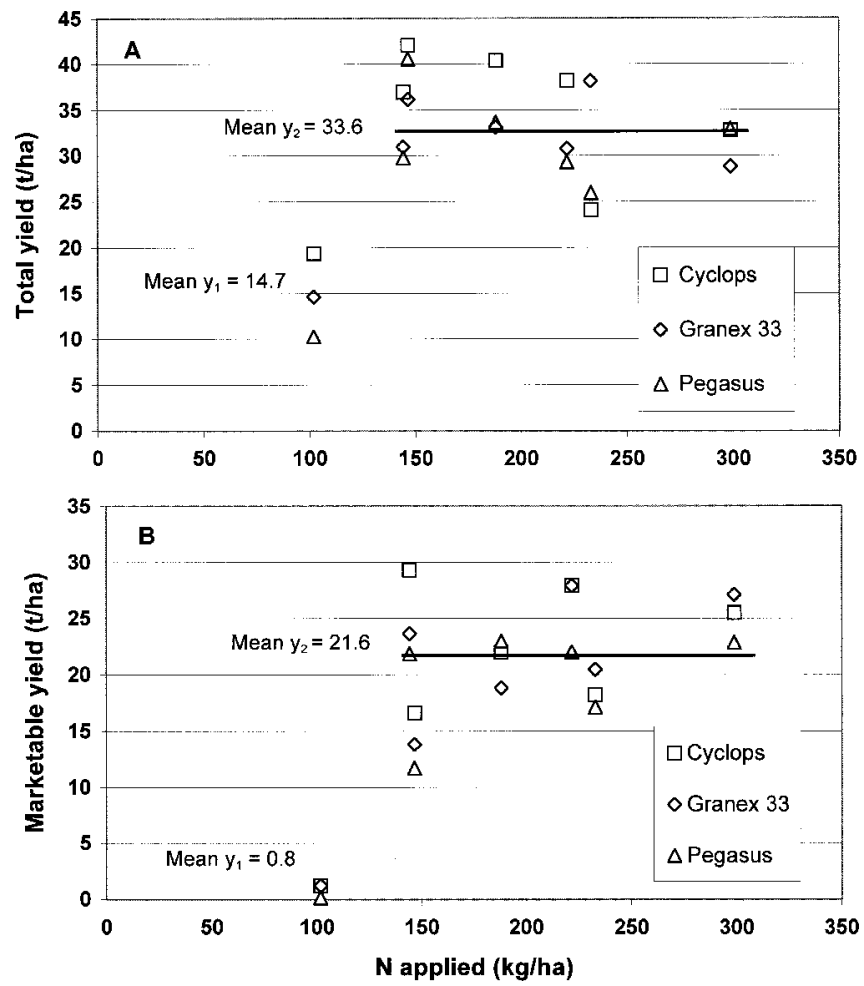

Fig. 5. Total (A) and marketable (B) yields as affected by the amount of nitrogen fertilizer applied. Data were pooled over seasons (1997-98 and 1998-99). Total and marketable yields, pooled for the two seasons and three cultivars and analyzed by nonlinear regression, resulted in a nonsignificant $\mathrm{F}$ value and thus in no significant trends. Means for marketable and total yields at $102 \mathrm{~kg} \cdot \mathrm{ha}^{-1} \mathrm{~N}$ $\left(\mathrm{y}_{1}\right)$ were significantly different $(P \leq 0.01)$ than yields at $\geq 146 \mathrm{~kg} \cdot \mathrm{ha}^{-1}$. Each symbol represents the mean for the cultivar at each $\mathrm{N}$ rate. Solids lines represent the mean for $\mathrm{N}$ rates $\geq 146 \mathrm{~kg} \cdot \mathrm{ha}^{-1}\left(\mathrm{y}_{2}\right)$.
Possibly, increasing $\mathrm{N}$ fertilization rates decreased onion plants' $\mathrm{C} / \mathrm{N}$ ratios. Thus, appropriate $\mathrm{N}$ fertilization at the time onion plants are susceptible to flower induction may be important in reducing the incidence of onion bolting.

Marketable and total yields were lowest at $102 \mathrm{~kg} \cdot \mathrm{ha}^{-1} \mathrm{~N}$ but were unaffected by $\mathrm{N}$ rates $\geq 146 \mathrm{~kg} \cdot \mathrm{ha}^{-1} \mathrm{~N}$. Losses in marketable yield were primarily a combination of bolting and bulb decay. Yield losses at low $\mathrm{N}$ rates were mostly due to bolting, while yield losses at high $\mathrm{N}$ rates were mostly due to decay. Nitrogen fertilization had opposite effects on bolting and bulb decay. Bolting decreased while bulb decay increased with increasing $\mathrm{N}$ rates. At $146 \mathrm{~kg} \cdot \mathrm{ha}^{-1} \mathrm{~N}$ (the lowest $\mathrm{N}$ rate at which total and marketable yields were highest), bolting incidence was about $47 \%$ and decay incidence $25 \%$, while at $197 \mathrm{~kg} \cdot \mathrm{ha}^{-1} \mathrm{~N}$, bolting was about $7 \%$ and decay incidence $53 \%$. Thus, $\mathrm{N}$ fertilization reduced bolting and increased decay, with yield losses being minimized at $162 \mathrm{~kg} \cdot \mathrm{ha}^{-1} \mathrm{~N}$. Applications of $\mathrm{N}$ fertilizer in excess of $197 \mathrm{~kg} \cdot \mathrm{ha}^{-1}$ are probably not recommended since they may have little effect on yields or bolting, but may significantly increase the incidence of bulb decay. Onion growers in the Vidalia area of Georgia typically apply about 155 to $180 \mathrm{~kg} \cdot \mathrm{ha}^{-1} \mathrm{~N}$ (Boyhan et al., 2001; Boyhan and Torrance, 2002). Batal et al. (1994) found that the yield and quality of sweet onions in Georgia were highest at $168 \mathrm{~kg} \cdot \mathrm{ha}^{-1} \mathrm{~N}$. We suggest that, in addition to the effects on yields, the effects of $\mathrm{N}$ fertilizer on bolting and bulb decay should also be considered.

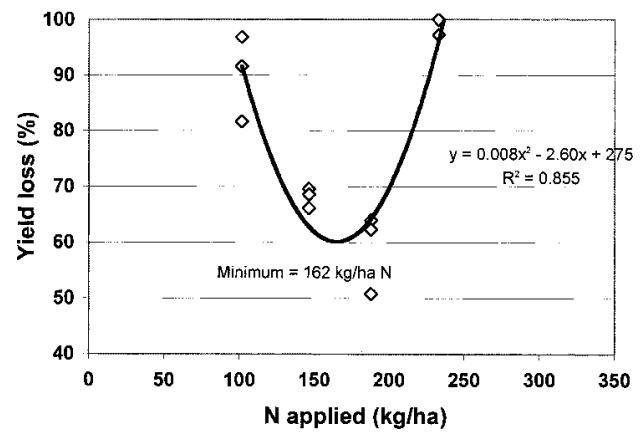

Fig. 6. Onion yield loss as affected by nitrogen rate of fertilization. Yield loss was calculated as the percent number of plants (relative to the total) lost from either bolting or bulb decay. Each symbol represents the mean of each onion cultivar at each $\mathrm{N}$ rate. Solid line was fitted by linear regression. 
Onion bolting is enhanced by low-temperature conditions (Rabinowitch, 1990). Bolting incidence was lower in the 199798 season than in 1998-99. However, the difference in bolting between seasons was probably not related to ambient temperature because average temperature in 1997-98 (14.3 $\left.{ }^{\circ} \mathrm{C}\right)$ was lower than in the $1998-99$ season $\left(15.8^{\circ} \mathrm{C}\right)$. Possibly, bolting differences between seasons were a result of the lower $\mathrm{N}$ rates applied in 1998-99 compared to 1997-98. Application of reduced N rates may also explain the reduced bulb $\mathrm{N}$ content in 1998-99 (Table 3 ). In addition to differences in $\mathrm{N}$ rates between the two seasons, $\mathrm{N}$ fertilizer applications were more frequent and were extended later in the season in 1997-98 compared to 1998-99 (Tables 1 and 2). Frequent $\mathrm{N}$ applications in sandy soils allow for more efficient $\mathrm{N}$ utilization by the crop (Keeny, 1982) and result in increased sweet onion yields (Batal et al., 1994). Plants under more frequent $\mathrm{N}$ applications are probably less affected by $\mathrm{N}$ deprivation due to leaching after heavy rains or irrigation. Thus, a more efficient fertilization program in 1997-98 probably increased $\mathrm{N}$ uptake throughout the growing season and resulted in less bolting, yields and high bulb and shoot $\mathrm{N}$ content. Georgia's coastal plain soils have a low water holding capacity, resulting in high rates of nutrient leaching after a heavy rain or irrigation (Hoyt et al., 1994). Thus, the possibility of nutrient leaching caused by excessive irrigation or excessive rainfall must also be considered in the $\mathrm{N}$ fertilization program for onion.

Fertilization is an important variable in the production of mild, sweet onions. Although sulphur is the element that has the greatest effect on onion pungency, high $\mathrm{N}$ fertilization has been found to increase pungency under field conditions (W.O. Chance and D.A. Smittle, personal communication) and in hydroponic studies (Randle, 2000). In our study, however, $\mathrm{N}$ fertilization had no significant effect on either bulb pungency (pyruvate formation of 2.3 and $4.3 \mu \mathrm{mol} \cdot \mathrm{g}^{-1} \mathrm{FW}$ for 1997-98 and 1998-99, respectively) or soluble solids content (8.3\% and $7.7 \%$ for $1997-98$ and 1998-99, respectively). Our results differed from those of Randle (2000) probably because $\mathrm{N}$ levels in his hydroponic study were high compared to typical field conditions in Georgia (the lowest $\mathrm{N}$ rate in the Randle's study corresponds to about $300 \mathrm{~kg} \cdot \mathrm{ha}^{-1}$ ). Thus, our results did not indicate the presence of an effect of $\mathrm{N}$ fertilization on onion pungency.

In summary, bolting decreased with increasing $\mathrm{N}$ fertilization and bulb $\mathrm{N}$ content. Nitrogen fertilization rates $>145 \mathrm{~kg} \mathrm{ha}^{-1} \mathrm{did}$ not affect marketable or total yields. However, excessive applications of $\mathrm{N}$ fertilizer $\left(>197 \mathrm{~kg} \cdot \mathrm{ha}^{-1}\right.$ ) should be avoided since they have little effect on increasing yields or reducing bolting, but they may significantly increase bulb decay.

\section{Literature Cited}

Anderson, R.L. and L.A. Nelson. 1975. A family of models involving intersecting straight lines and concomitant experimental designs useful in evaluating response to fertilizer nutrients. Biometrics 31:303-318.

AOAC. 1990. Official methods of analysis. Assn. Off. Anal. Chem., Wash. D.C. p. 74.

Argo, W.R. and J.A. Biernbaum. 1996. The effect of lime, irrigationwater source, and water-soluble fertilizer on root-zone $\mathrm{pH}$, electrical conductivity, and macronutrient management of container root media with impatiens. J. Amer. Soc. Hort. Sci. 121:442-452.
Batal, K.M., K. Bondari, D.M. Granberry, and B.G. Mullinix. 1994. Effects of source, rate, and frequency of $\mathrm{N}$ application on yield, marketable grades and decay incidence of sweet onion (Allium cepa $\mathrm{L}$. cv. Granex-33). J. Hort. Sci. 69:1043-1051.

Boyhan, G.E., D.M. Granberry, and W.T. Kelley (eds.). 2001. Onion production guide. Univ. Ga. College Agr. Environ. Sci. Bul. 801.

Boyhan, G.E. and R.L. Torrance. 2002. Vidalia onions-Sweet onion production in southeastern Georgia. HortTechnology 12:196-202.

Brewster, J. L. 1983. Effects of photoperiod, nitrogen nutrition and temperature on inflorescence initiation and development in onion (Allium cepa L.). Ann. Bot. 51:429-440.

Brewster, J.L. 1985. The influence of seedling size and carbohydrate status and of photon flux density during vernalization on inflorescence initiation in onion (Allium cepa L.). Ann. Bot. 55:403-414.

Brewster, J.L. 1997. Onions and garlic, p. 581-619. In: H.C. Wien (ed.). The physiology of vegetable crops, CAB Intl., Ithaca, N.Y.

Dennis, F.G. Jr. 1984. Flowering, p. 237-264. In: M.B. Tesar (ed.). Physiological basis of crop growth and development. Amer. Soc. Agron., Madison, Wis.

Hoyt, G.D., D.C. Sanders, J.T. Garret, K.M. Batal, J.M. Davis, D.R. Decoteau, and R.J. Dufault. 1994. Nitrate movement in southeastern coastal soils under conservation-tilled vegetable production, p. 120 123. Proc. S. Conservation Tillage Conf. for Sustainable Agr., Columbia, S.C.

Keeny, D.R. 1982. Nitrogen management for maximum efficiency and minimum pollution, p. 605-649. In: F.J. Stevenson, J.M. Bremner, R.D. Hauck, and D.R. Keeney (eds.). Nitrogen in agricultural soils. Amer. Soc. Agron., Madison, Wis.

Marschner, H. 1995. Mineral nutrition of higher plants. $2^{\text {nd }}$ ed. Academic Press, London.

Paterson, D.R. 1984. Influence of nitrogen and phosphorus fertilizer on respiration rate, premature seedstalk formation and yield of yellow granex onions. J. Rio Grande Valley Hort. Soc. 37:33-41.

Paterson, D. R., H.T. Blackhurst, and S.H. Siddiqui. 1960. Some effects of nitrogen and phosphoric acid on premature seedstalk development, yield and composition of three onion varieties. Proc. Amer. Soc. Hort. Sci. 76:460-467.

Rabinowitch, H.D. 1990. Physiology of flowering, p. 113-134. In: H.D. Rabinowitch and J.L. Brewster (eds). Onions and allied crops. CRC Press, Boca Raton, Fla.

Randle, W.M. 2000. Increasing nitrogen concentration in hydroponic solutions affects onion flavor and bulb quality. J. Amer. Soc. Hort. Sci. 125:254-259.

Roberts, E.H., R.J. Summerfield, R.H. Ellis, P.Q. Craufurd, and T.R. Wheeler. 1997. The induction of flowering, p. 69-99. In: H.C. Wien (ed.). The physiology of vegetable crops. CAB Intl., Ithaca, N.Y.

Sanders, D.C. and J.D. Cure. 1996. Control of bolting in autumn-sown sweet onions through undercutting. J. Amer. Soc. Hort. Sci. 121:11471151.

SAS Institute Inc. 2000. SAS / C OnlineDoc. Release 7.00. SAS Inst. Inc., Cary, N.C.

Scully, N.J., M.W. Parker, and H.A. Borthwick. 1945. Interaction of nitrogen nutrition and photoperiod as expressed in bulbing and flowerstalk development of onion. Bot. Gaz. 107:52-61.

Steel, R.G.D. and J.H. Torrie. 1980. Principles and procedures of statistics. A biometrical approach. McGraw-Hill, New York.

Stuart, N.W. and D.M. Griffin. 1946. The influence of nitrogen nutrition on onion seed production in the greenhouse. Proc. Amer. Soc. Hort. Sci. 48:398-402.

U.S. Department of Agriculture. 1995. U.S. standards for grades of Bermuda-granex-grano type onions. USDA, Wash., D.C. 